\title{
Pragmatism, Critical Theory and Business Ethics: Converging Lines
}

\author{
Max Visser ${ }^{1}$
}

Received: 25 October 2016/Accepted: 27 April 2017/Published online: 11 May 2017

(C) The Author(s) 2017. This article is an open access publication

\begin{abstract}
There is a "Pragmatist turn" visible in the field of organization science today, resulting from a renewed interest in the work of Pragmatist philosophers like Dewey, Mead, Peirce, James and others, and in its implications for the study of organizations. Following Wicks and Freeman (1998), in the past decade Pragmatism has also entered the field of business ethics, which, however, has not been uniformly applauded in that field. Some (Critical) scholars fear that Pragmatism may enhance already existing positivist and managerialist tendencies in current business ethics, while others see more emancipatory potential in Pragmatism, arguing that it complements and supports stakeholder theory. In this paper, a comparison of the philosophical underpinnings of Pragmatist and Critical conceptions of business ethics is offered, concentrating on the Pragmatism of John Dewey and the Critical theory of the Frankfurt School, in particular of Axel Honneth. It is argued that these two developed along two converging lines. Along the first line, Dewey was far more skeptical and critical of capitalism than is often thought. Along the second line, the reactions to Pragmatism of Frankfurt School Critical theorists developed over time from generally hostile (Horkheimer, Marcuse), to partially inclusive (Habermas), to more fully integrative (Honneth). At the crossroads of these converging lines a Pragmatist Critical perspective is developed and exemplified, and its implications for business ethics are outlined.
\end{abstract}

Max Visser

m.visser@fm.ru.nl

1 Institute for Management Research, Radboud University, PO Box 9108, 6500 HK Nijmegen, The Netherlands
Keywords Pragmatism - Critical theory · Frankfurt school · John Dewey · Axel Honneth

\section{Introduction}

There is a "Pragmatist turn" visible in the field of organization science today, resulting from a renewed interest in the work of Pragmatist philosophers like Dewey, Mead, Peirce, James and others, and in its implications for the study of organizations (e.g., Farjoun et al. 2015; Keleman and Rumens 2008; Martela 2015; Simpson 2009). The influence of Pragmatism appears most visible in studies of organizational learning (e.g., Argyris and Schön 1996; Brandi and Elkjaer 2004, 2011 ), organizational routines (e.g., Cohen 2007; Winter 2013), reflective practice (e.g., Jordan 2010; Schön 1992; Yanow and Tsoukas 2009) and sensemaking (e.g., Colville et al. 2014; Elkjaer and Simpson 2011; Weick 2004, 2006). Following Wicks and Freeman (1998), in the past decade Pragmatism has also entered the field of business ethics (e.g., Jacobs 2004; Jensen and Sandström 2013; Singer 2010; Surie and Ashley 2008).

This emerging "Pragmatist turn" in business ethics has not been uniformly applauded in the field. Some scholars, in particular those involved in Critical management studies, fear that Pragmatism may enhance already existing positivist and managerialist tendencies in current business ethics, intent on prescribing rules, codes and guidelines for managerial conduct that, however, do not touch on the nature of the capitalist production system, with its emphases on profit, efficiency and productivity (e.g., Painter-Morland and Ten Bos 2016; Parker 2003; Stokes 2011; Wray-Bliss 2009). Other scholars see more emancipatory potential in Pragmatism, arguing that it 
complements and supports stakeholder theory, in which managers and firms are exhorted to look beyond narrow shareholder interests to include environmental concerns and the interests of employees, clients and the communityat-large (e.g., Jacobs 2004; Parmar et al. 2010; Wicks and Freeman 1998).

Underlying this dissension about the "Pragmatist turn" in business ethics appears to be the question to what extent Pragmatist and Critical conceptions of business ethics are compatible in a philosophical and a practical sense (Painter-Morland and Ten Bos 2011; Singer 2010). This paper intends to address that question. To do that in a somewhat manageable way, it is proposed to pin down both conceptions to more concrete philosophers and schools. Regarding Pragmatism, this paper concentrates on John Dewey (1859-1952). Arguably more than that of Mead, Peirce or James, Dewey's work has been instrumental in making Pragmatism dominant in American philosophy (Bernstein 2010; Evans 2000; Keleman and Rumens 2008). Current day philosophers of different stripes have publicly classed Dewey with Wittgenstein, Russell and Heidegger as one of the most influential philosophers of the twentieth century (Habermas 1998; Rorty 2003). Furthermore, Dewey's work appears particularly important for organizational and public life:

More fully than any other philosopher of modern times, Dewey put philosophy to the service of society... The ends he sought were public, not private. Truth was, to him, not merely what worked for the individual but what worked for the group, and it was to be achieved by cooperative action (Commager 1950, p. 99; Stever 1993; Thayer 1967).

Regarding Critical theory, this paper concentrates on the Frankfurt School in social philosophy, in particular on the work of Axel Honneth. The work of this School is commonly regarded as a particularly important source of theoretical inspiration of Critical management and organization studies (e.g., Adler et al. 2008; Alvesson et al. 2009; Carr 2000; Jermier 1998; Visser 2010). Among current third-generation Frankfurt scholars, Axel Honneth "figures as the undisputed gravitational center" (Anderson 2011, p. 46; Keucheyan 2013; Outhwaite 2009; Zurn 2015), whose "ideas have yet to be widely taken up by Critical students of management" (Alvesson and Willmott 2012, p. 261; Scherer 2009).

To address this question, the argumentation of this paper runs along two converging lines. Along the first line, the Pragmatism of Dewey is broadly outlined, whereby it is asserted that Dewey was far more skeptical and critical of capitalism than is often thought, by mainstream organizational scientists and Critical theorists alike. Along the second line, the reactions to Pragmatism of those Critical theorists are outlined, which developed over time from generally hostile (Horkheimer, Marcuse), to partially inclusive (Habermas), to more fully integrative (Honneth) (Hartmann 2009; Joas 1992, 1993; Zurn 2015). At the crossroads of these converging lines, a Pragmatist Critical perspective is developed and discussed on the basis of a concrete case example, after which implications for business ethics are outlined. Finally, the paper ends with discussion and conclusions. Throughout this paper, business ethics is defined as the "discipline of questioning whether we still agree with what is commonly accepted as right and wrong in [organizations]" (Painter-Morland and Ten Bos 2011, p. 9).

\section{Pragmatism, Dewey and Social Intelligence}

Pragmatism as a general philosophy arose as a distinct American revolt against Idealism in late nineteenth and early twentieth century philosophy (Commager 1950; Hollinger 1980). Inspired by Darwin's theory of evolution, Pragmatists in general emphasized the variations and struggles of the organism in meeting and coping with the environment (Almeder 1987; Ormerod 2006).

Initially inspired by Hegel, but later on "naturalizing Hegel" by building on Darwin, Dewey viewed this meeting and coping as a transaction between the organism and its environment (Bernstein 2010, p. 92; Frega 2015; Smith 1973). However, from Hegel he retained the notion of "the social organism [and] worked from the fundamental belief that individual self-realization, the central motif of his early and late ethical theory, is bound to the development of the whole" (Deen 2013, pp. 649-650, italics added; Zanetti and Carr 2000). Further, he retained from Hegel an emphasis on wholes and a rejection of dualisms. Thus, for example, he rejected the artificial distinction between stimuli and response, popular in early twentieth century behaviorist psychology (Dewey 1896): "the so-called stimulus, being the total state of the organism, moves of itself, because of the tensions contained, into those activities... which are called the response. The stimulus is simply the earlier part of the total coordinated serial behavior and the response the later part" (Dewey 1938, p. 30; Lee 1973).

On this basis, transaction as a balanced, coordinated and effectively integrated adaptation involves habits: flexible but ordered activities, established on the basis of past successfully consummated activities of exploration and search. However, these habits may at any point be disturbed by changes in the environment and in the human individual, as it grows and develops itself. In fact, the continuous dynamic of order-interruption-recovery is a fundamental feature of human experience, according to Dewey (1922, pp. 178-179; 
Smith 1973): "The truth is that in every waking moment, the complete balance of the organism and its environment is constantly interfered with and as constantly restored... Life is interruptions and recoveries..."

Such interruptions in the continuity of experience, understanding and acting lead to an indeterminate or problematic situation, seeded with doubt and full of uncertainty and conflicting tendencies. It is important to note that, to Dewey, indeterminacy is a characteristic of the situation viewed as a "contextual whole... [in which] an object or event is always a special part, phase or aspect, of an environing experienced world... there is always a field in which observation of this or that object or event occurs" (Dewey 1938, pp. 66-67; original italics). As such, indeterminacy is not reducible to the mental states of the individuals in that situation: "We are doubtful because the situation is inherently doubtful." Attempts to clear up an indeterminate situation by only attending to the states of mind of the individuals involved would in fact encourage withdrawal from reality and other pathological symptoms. Instead, the indeterminate situation should be subject to a process of inquiry, bringing forth the phase of recovery (Dewey 1938, p. 105; Smith 1973).

Inquiry is defined by Dewey (1938), pp. 104-105 as "the controlled or directed transformation of an indeterminate situation into one that is so determinate in constituent distinctions and relations as to convert the elements of the original situation into a unified whole." As such, inquiry involves a "reflective evaluation of existing conditions - of shortcomings and possibilities - with respect to operations intended to actualize certain potentialities of the situation so as to resolve what was doubtful" (Thayer 1967, pp. 434-435). Moving toward determination of a problematic situation involves dialectically progressive steps toward searching out the constituents of a given situation and settle them by observation, develop ideas about possible solutions, and put them into operation (Dewey 1938; George 1973).

Inquiry primarily takes place in a social context, since human individuals are subject to shared problems and dependent upon each other for survival. Inquiry as a social process includes a community of inquirers who reach agreement upon consequences, and thus jointly confirm or correct results and outcomes of inquiry. Conducive to this process is democracy, and Dewey favored extending the reach of democracy from the political arena to other parts of society, such as education and industrial organizations. In this way, individuals would be enabled to use inquiry to critique and redevelop these organizations in social and intelligent ways (Deen 2011; Dewey 1938; Ormerod 2006; Williams 1970).

This was important to Dewey, because he saw an essential role for public and private organizations in sustaining human freedom and liberal democracy against the threats of modern technology and technocracy. These threats involved disorientation and confusion among citizens, which could lead to pervasive institutional change, and most importantly, to social and cultural instability (Evans 2000; Stevers 1993). Dewey was ambivalent about these organizations, in particular about the new industrial corporations of his days. On the one hand, he admired their efficiency and effectiveness, and saw important moral obligations for them in sustaining and reforming society. At least in principle, the societal division of labor in these corporations permitted ever more cooperation and exchange of goods and services, and thus afforded "one the fundamental expressions of the organic nature of society in which members are reciprocally ends to each other" (Dewey and Tufts 1908, p. 486). Even machine production could be viewed positively in this light, because "it is the machine which makes possible on a tremendously effective basis the division of labor and its social organization" (Dewey and Tufts 1908, p. 507; Deen 2013).

On the other hand, Dewey saw that these large corporations, and the capitalist economic system that sustained them, did not fulfill these moral obligations. On the contrary, their "exclusive reliance upon the profit motive and upon the supreme importance of wealth tends to distort the proper perspective for life as a whole" (Dewey and Tufts 1908, p. 488). This distortion was endemic to American society as a whole, with its emphasis on money and materialism:

Our materialism, our devotion to money making and to having a good time, are not things by themselves. They are the product of the fact that we live in a money culture; of the fact that our technique and technology are controlled by interest in private profit. There lies the serious and fundamental defect of our civilization (Ratner 1939, p. 405; Williams 1970).

The capitalist system in fact prevented a rational, intelligent organization of society, to the extent that it represented a waste of labor and resources by alienating workers from their work and its fruits, by failing to provide them with an opportunity to contribute their physical, intellectual and moral energies to the attainment of the common good, and by restricting production in the name of profit maximization where expansion of production would be desirable and necessary for society as a whole (Deen 2013; Evans 2000; Williams 1970):

Making things is frantically accelerated; and every mechanical device used to swell the senseless bulk. As a result most workers find no replenishment, no renewal and growth of mind, no fulfillment in work. They labor to get mere means of later satisfaction. 
This when procured is isolated in turn from production and is reduced to a barren physical affair or a sensuous compensation for normal goods denied. Meantime the fatuity of severing production from consumption, from present enriching of life, is made evident by economic crises, by periods of unemployment alternating with periods of exercise, work or "over-production" (Dewey 1922, p. 272).

The development of the corporations should not be separated from developments in society and technology. Extolling the virtues of capitalism and its captains of industry distracted attention from the basic fact that

the entire modern industrial development is the fruit of the technological applications of science. By and large, the economic changes of recent centuries have been parasitic upon the advances made in natural science. There is not a single process involved in the production and distribution of goods that is not dependent upon the utilization of results which are consequences of the method of collective, organic intelligence working in mathematics, physics, and chemistry. To speak baldly, it is plain falsehood that the advances which the defenders of the existing regime point to as justification for its continuance are due to mere individualistic initiative and enterprise. Individualistic initiative and enterprise have sequestered and appropriated the fruits of collective cooperative intelligence... Without the aid and support of organized intelligence they would have been impotent (Ratner 1939, pp. 360-361).

To remedy this situation, Dewey envisioned an "intelligent social control of production," restructuring corporations into vital, experimental and democratic organizations that should be able to solve societal problems through dialectical cooperation between managers, employees and citizens in a community-like fashion (Deen 2013, p. 651; Stever 1993).

\section{Critical Theory and the Reception of Deweyan Pragmatism}

The Critical theory of the Frankfurt School arose as a distinct German philosophical reaction against the capitalist mode of production in the late nineteenth and early twentieth century and the accompanying dominant position of instrumental reason in capitalist society. Inspired by Hegel's dialectics, Marx's critique of capitalism and Lukács's radical reinterpretation thereof, Freudian psychoanalysis, and Weber's thesis of the "iron cage," Critical theorists in general critiqued the loss of individual freedom and self-actualization, resulting from alienating and reifying capitalist and bureaucratic forces that turn human subjects into exchangeable objects or commodities ("Verdinglichung") (Honneth 2004a, 2008; Jay 1973; Keucheyan 2013; Langman 2014).

In an early important programmatic paper, Max Horkheimer (1937) made a fundamental distinction between "traditional" and "Critical" theory. Traditional theory is distinct and separate from reality. It aims to develop universal systems of theories, from which hypotheses are deduced that are compared to empirical observations in a process of verification. While traditional theorists thus seem to remain aloof of the reality they are studying, what they are really doing is to treat their own activities, which are governed by the societal division of labor (i.e., capitalism), as having an objective and independent status.

Critical theory rejects the "traditional" differentiations between science and the world, objects and subjects, the theoretical and the empirical, fact and value. Instead of viewing interests and purposes as given facts, Critical theory

attempts to impart to social life in its totality a rational form and does not limit itself to working within the framework of the given system of the division of labor... [It] is confronted with the task of justifying its own problems and their differentiation and has to adjust its internal structure accordingly. It does not set up an unchanging system but sees as its purpose the attempt to apply the knowledge that has been accumulated in the traditional theories to the social totality in the direction that Critical theory itself indicates (Horkheimer 1937, pp. 292-293).

One promising way to do this is to investigate the actual activities of social agencies in the light of their espoused values, without prima facie accepting these as valid or evident, but also without resorting to a normative dogmatism that would somehow be beyond a Critical analysis itself. Such an investigation most likely

will disclose a pervasive discrepancy between what [social agencies] actually are and the values they accept. [For] example, the media of public communication ... constantly profess their adherence to the individual's ultimate value and his inalienable freedom, but they operate in such a way that they tend to forswear such values by fettering the individual to prescribed attitudes, thoughts, and buying habits. The ambivalent relation between prevailing values and the social context forces the categories of social theory to become Critical and thus to reflect the actual rift between the social reality and the values it posits (Horkheimer 1941, p. 122). 
In this endeavor, almost from the moment the Frankfurt School had completed its forced emigration from Hitler's Germany to Columbia University in 1934, its leading members engaged with philosophical Pragmatism. In general, they adopted a one-sided, hostile position toward it (e.g., Adorno 1941; David 1937; Horkheimer 1935, 1937). Partly this occurred because the "Frankfurt School generally remained outside the mainstream of American academic life. This allowed it to make assumptions, such as the equation of pragmatism with positivism, that lacked complete validity" (Jay 1973, p. 289), and which made them overlook the early but distinct Hegelian imprint in Dewey's thinking. Partly this occurred because Dewey's economic thinking was dispersed over a vast number of philosophical and non-theoretical works, and thus hard to fathom in its entirety (Bernstein 2010; Deen 2013).

Horkheimer in particular saw Dewey as the most radical and consistent Pragmatist philosopher. He critiqued Dewey's Pragmatism as "scientism," in which "probability, or better, calculability replaces truth," and related it directly to industrial society and its accompanying instrumental reason (Horkheimer 1947, p. 44). Although Horkheimer acknowledged Dewey's idea of freedom as the fulfillment of desires and aspirations of people, reminiscent of Hegel's ideal of self-realization, he chided Dewey for accepting these desires and aspirations at face value:

First, it may be taken to refer to the desires of people as they really are, conditioned by the whole social system under which they live a system that makes it more than doubtful whether their desires are actually theirs. If these desires are accepted in an uncritical way, not transcending their immediate, subjective range, market research and Gallup polls would be a more adequate means for ascertaining them than philosophy. Or, second, Dewey somehow agrees to accept some kind of difference between subjective desire and objective desirability. Such an admission would mark just the beginning of Critical philosophical analysis... (Horkheimer 1947, pp. 53-54).

The same themes appeared in two reviews of Dewey's books by Herbert Marcuse (1939, 1941). His first review (of Dewey's Logic) critiqued the reduction of theory to mere method, which he saw exemplified in Dewey's concept of inquiry. His second review (of Dewey's Theory of Valuation) recalled how the original critical stance of positivism and reason in relation to a given state of affairs gradually became lost, and how this loss left Pragmatism as positivism powerless to the rise of authoritarianism in Europe. In this context Marcuse reviewed Dewey's theory of valuation, because Dewey had been mainly responsible for bringing value judgments in the realm of positivist science. Contrary to positivism, however, Dewey did seem to apply a pre-theoretical standard or perspective, according to which these ends can be revaluated, "namely, that liberty and the 'release of individual potentialities' is better than its opposite" (Marcuse 1941, p. 148). Dewey was optimistic that if people should become conscious of special class privileges and advantages, they would come to revaluate them. Marcuse, however, cognizant of earlier Frankfurt School research on authoritarian tendencies among the German working class (Fromm 1932, 1936, 1941, 1984) and already foreshadowing later research on the authoritarian personality (Adorno et al. 1950) was much more pessimistic (Deen 2011).

Contrary to first-generation Critical theorists, secondgeneration Critical theorists like Habermas found ways to partially include elements of Pragmatism in their Critical philosophy, but still without cognizing Dewey's economic thinking. By the late 1960s, first-generation Critical theorists had come to the conclusion that instrumental reason had taken such a pervasive dominating hold on modern society that even Critical philosophy itself had become affected by it (Adorno 1966; Rose 1978). Progressively rationalizing forces of bureaucracy and capitalism had "reified" the human spirit to such a large extent that remnants of true spontaneity and freedom only could be found in the irrational powers of love and art (Anderson 2011; Honneth 2005; Thompson 2015).

Habermas undertook a reconstruction of Critical theory "by embracing the real achievements of bourgeois democracy while salvaging the project of modernity specifically through a mobilized public sphere, revitalized public discourse and personal involvement in politics" (Ray 2004, p. 309). An important role in this reconstruction was played by Peirce's "universal pragmatics," which focuses on an intersubjectively founded validity of beliefs as both the process and outcome of inquiry. Unlike firstgeneration Critical theorists, Habermas no longer regarded the normative wrongness of rationalizing bureaucratic and capitalist forces as self-evident, but his "theory of communicative action locates the potential for an anthropologically grounded reason... in the quintessentially human activity of reaching a linguistically mediated understanding" (Ray 2004, p. 309; Strydom 2011). This potential enabled Habermas to focus on the specific conditions under which human communication could be free from domination (the "ideal speech" situation), while at the same time still critiquing the domination of instrumental rationality, found in the "mediatization," "instrumentalization" and "colonization" of the "life world" by capitalist and bureaucratic "systems" (Anderson 2011; Joas 1993; Ray 2004).

While Habermas incorporated aspects of especially Peirce's pragmatics in his theory of communicative action, in three other aspects he remained distant from especially 
Dewey's Pragmatism. First, like Horkheimer (1947) and Marcuse (1941) before him, Habermas did not share the democratic optimism of Dewey (and Peirce for that matter). Partly based on German historical experience and partly on "his theoretical commitment to a vigilant conception of Critical reason," Habermas distrusted common sense and was very doubtful about the possibilities of reconstructing industrial corporations and political systems in more democratic and experimental ways, as Dewey envisioned (Anderson 2011, p. 42; Denzin 1996; Joas 1992). Second, this aloofness from Dewey's "problems of men" gave Habermas' theory an abstract, quasi-transcendental character that makes it difficult to connect the requirements of "ideal speech" situations to concrete agency in the political or organizational world (Denzin 1996; Peters 1994; Ray 2004). Third, Habermas' theory appeared to privilege consensus over continuous and relentless inquiry, ignoring that consensus always involves power and some form of exclusion, for example of weaker voices defined by class, race or gender (Cohen 1990; Denzin 1996; Zanetti and Carr 2000).

\section{Honneth and Dewey: Toward Convergence}

It remained for the leading third-generation Critical theorist Axel Honneth to more fully integrate Dewey's Pragmatism with Critical philosophy, including parts of Dewey's economic thinking (Anderson 2011; Frega 2015; Midtgarden 2012; Strydom 2011; Zurn 2015). Fundamental to Honneth's social philosophy is Hegel's conception of freedom as intersubjectively constituted through mutual recognition. It is essential for the self-realization and identity development of persons to be recognized by other persons (Brownlee 2015; Honneth 2010a; 2014; Klikauer 2012). Self-realization as the development of a positive individual identity requires three patterns of recognition. The first pattern, love, refers to the degree to which affective and physical needs are met by proximal significant others and provides basic self-confidence. Misrecognition and disrespect here involve contempt as the violation of physical and psychological integrity. The second pattern, respect, refers to the degree to which persons are seen as morally responsible agents and bearers of equal legal, social and political rights and provides self-respect. Misrecognition and disrespect here involve structural exclusion as the denial of legal, social and political rights to fully participate in and be respected as a member of society. The third pattern, esteem, refers to the degree to which traits and abilities of persons are positively perceived and evaluated and provides self-esteem. Misrecognition and disrespect here involve the denial or depreciation of a person's contribution to a group or society, based on that person's traits, convictions, ways of life and other attributes (Honneth 1992, 1995, 2001).

Misrecognition and disrespect, either by individuals, groups or society at large, convey a demeaning, degrading or debasing message to persons or groups, which may inflict real psychological and social harm and pain on those persons or groups. As such, misrecognition and disrespect constitute a violation of moral claims and normative expectations persons and groups may have with regard to the three patterns of recognition. The negative and painful subjective "lived" experiences and emotions they undergo and the struggle for societal recognition they undertake as a result provide the normative core of Honneth's social critique (Anderson 2011; Outhwaite 2009; Strydom 2011).

Rather than viewing the historical development of society in terms of grand meta-narratives like the "eclipse of reason" or the "colonization of the life world," Honneth directly goes to normative expectations that are available in society itself in a process of normative reconstruction (Honneth and Sutterlüty 2011). Here Honneth suspects the existence of pathological societal structures which may structurally frustrate these normative expectations (Anderson 2011; Honneth 2004a, 2010b; Outhwaite 2009).

Such structures principally emerge from globalizing capitalism, but to a differential degree throughout recent history. In the two decades after World War II, a stateregulated capitalism emerged in which four normative expectations were simultaneously realized: individualism as a leading personal idea; an egalitarian conception of legal and political justice; the idea of achievement as the basis of social status; and the romantic idea of love. Together these four expectations form an "institutionalized normative surplus... [allowing] legitimizable claims that point beyond the established social order" (Hartmann and Honneth 2006, p. 42; Islam 2012; Zurn 2015).

In all of these four areas, there has been considerable moral progress in the era from the late 1960s to the early 1980s. However, a demise of state-regulated capitalism began in the 1980s, and continues until the present, as a "neo-liberal revolution" with three characteristics: disorganized capitalism (characterized by globalizing firms, internationalization of finance flows, fading of class-cultural ties and weakening welfare state rules and safeguards); shareholder capitalism (leading to shareholderoriented management to the detriment of interests of other stakeholders in firms) and the new spirit of flexible network capitalism (requiring employees to invest their personal abilities, motivations and emotional resources in their work, instead of fulfilling hierarchically predetermined jobs within large organizations). This neo-liberal capitalism has led to a reversal of these four institutionalized normative expectations into normative paradoxes (Hartmann and Honneth 2006; Honneth 2004b, 2010b; Johnson 
2014). Reminiscent of Horkheimer's (1941) exhortation to look at "pervasive discrepancies" between espoused values and actual activities of social agencies, the normative paradoxes point at such discrepancies in current organizations and society.

For example, a reversal of the normative expectation of individualism is visible in the view of employees as variously entrepreneurs of their own labor, intrapreneurs or entreployees within their organizations, or as flexible human resources taking responsibility for themselves. This reversal is ethically problematic, because this particular expectation of individualism is not matched by appropriate material conditions "that would allow a consistent realization of these new values. Instead, employees are compelled to feign initiative, flexibility, and talents in places where there are no roots for such values" (Honneth 2007, p. 346; Islam 2012). The translation in fact involves a paradoxical reversal of self-realization, from a feature of personal identity development and growth into a institutionalized, efficiency enhancing expectation, used as a pretext for the deregulation, flexibilization and "marketization" of society, leading to symptoms of inner emptiness, lack of purpose, burnout and feelings of superfluity within employees (Honneth 2004b, 2007, 2010b; Petersen and Willig 2004; Strydom 2011).

In the development of this thinking, Honneth (1998, 2008, 2014) increasingly related to Dewey, in three aspects (Frega 2015). The first aspect regards the development of freedom as human self-realization, which Dewey, naively Hegelian, first assumed to develop freely and spontaneously in the direction of fulfilling social obligations and contributing to the social whole. This being too optimistic, Dewey then developed an

intersubjectivist theory of socialization... [in which humans] from completely open drives... can develop only those capabilities and needs as stable habits of action that have met with approval and esteem of their particular reference group... in the course of a development of a personality, only socially useful habits of action are formed (Honneth 1998, pp. 771-772).

In this way, social cooperation is constituted by a form of social behaviorism (Dewey 1896; Lee 1973): through identification with and recognition by reference groups, human freedom as self-realization becomes socially embedded.

The second aspect regards the logic of inquiry that Dewey took over from the logic of scientific research and applied to society at large as a condition for social intelligent problem-solving:

in social cooperation... the intelligence of the solution to emerging problems increases to the degree to which all those involved could, without restraints and with equal rights, exchange information and introduce reflection... Dewey developed an epistemological argument that proposed democracy as a condition for increasing the rationality of solutions to social problems... guarantee[ing] all members of society something like communication free of domination (Honneth 1998, pp. 772-773, 2014 p. 272; Zurn 2015).

The third aspect regards the internal connection between social cooperation and democracy. Dewey saw that the industrialization and concurrent growth in scale and complexity of societal problems in his days did not enhance the possibilities for grand-scale public inquiry into those problems. However, for Dewey the solution for the

revitalization of democratic publics [was] located in the prepolitical sphere of the social division of labor, which has to be regulated in such a fair and just manner that each member of society can understand herself as an active participant in a cooperative enterprise (Honneth 1998, p. 777,2014 pp. 330-331; Zurn 2015).

\section{A Pragmatist Critical Perspective on Business Ethics: The Lidl Case}

Through the various links between Honneth and Dewey, the lines of Pragmatism and Critical theory appear to converge at a Pragmatist Critical perspective (Frega 2014, 2015; Midtgarden 2012), which provides a normative context for business ethics. This perspective acknowledges the pre-theoretical importance of human freedom and selfrealization, seen as intersubjectively constituted through mutual recognition. Humans generally have the capacity to engage in societal and organizational problem-solving through inquiry, seen as a process of social cooperation and reflection. Democracy in society and organizations is considered as a crucial condition for intelligent and rational problem-solving, because it permits the application of the mental, intellectual and physical capabilities of all people involved. However, this perspective is generally suspicious about the effects of the capitalist system on the possibilities for human self-realization, cooperative inquiry and intelligent problem-solving. Especially under the neo-liberal capitalism of last three decades, normative expectations about the recognition people may receive from and within public and business institutions and organizations are potentially structurally frustrated and turned into normative paradoxes, which endanger the possibilities for people to equally take part in and contribute to cooperative inquiry. 
Such normative paradoxes become directly visible as pervasive discrepancies between the promises and expectations that organizations and society espouse, but at the same time do not match (or even grossly contradict) with appropriate social, material and organizational conditions that could realize these expectations.

In order to illustrate this Pragmatist Critical perspective, the case example of the German retail discounter Lidl is considered here. Founded in 1973 by Dieter Schwarz, it is currently the second largest "hard discounter" in Germany and rapidly expanding across Europe and the UK. In terms of espoused employment and working conditions, on its website Lidl (2017) promulgates a "management culture" in which it promises "to create a working environment that encourages initiative and drive and promotes enjoyment and satisfaction at work, [enabling] employees to work effectively and successfully... and [to] support employees' development." This culture is supported by "management principles" like:

We place confidence in our employees and trust that they will complete all tasks to the best of their ability, and that they will develop ideas and suggestions that will benefit our business; we speak to each other openly and promote honest, prompt and direct communication; we treat each other fairly and respectfully; we honor our agreements with our employees as a trustworthy partner; we give regular feedback to our employees on their performance and conduct; we support and motivate by recognition of achievements and constructive criticism.

In terms of actual employment and working conditions, however, the situation is quite different. These conditions by Lidl across Europe are informed by a business model that predominantly focuses on cost leadership, leading at store level to an

...enormous management pressure to meet a few key performance measures: sales per hours worked, sales in relation to labor costs, waste ... and inventory loss. There are a myriad of standard operating procedures in place in stores that are regularly controlled and closely coupled with a system of sanctions and repressive measures against store managers and employees if they "underperform" (Geppert 2015, pp. 100-101).

Under these conditions, verbal abuse and psychological and physical intimidation by managers are the order of the day. As a former employee attests, "they scream and yell at you as if you were a small child, people who by their age could have been my children." After each working day, employees' coats, handbags and cars were routinely searched for stolen goods, leading to an atmosphere in which employees showed up without coats or bags "for fear, they would put something in my pockets" (Steinberger 2010, translation author). Also, for a long time Lidl employed detectives who kept detailed records on employees' private lives, for example where exactly on their bodies they had tattoos, whether their friends used drugs, and how their personal financial situation developed. Within the stores, records were kept of employees' toilet visits during working hours and even of their menstrual cycles: an internal memorandum at a Lidl store advised that "female workers who have their periods may go to the toilet now and again, but to enjoy this privilege they should wear a visible headband" (Connolly 2008; Geppert 2015).

Further, the exact governance structure of the overarching Schwarz Group is unusually opaque, likened by a German services union representative to a sewing pattern with "hundreds if not thousands of overlapping and interconnected companies." Shares are divided between two foundations in order to avoid publishing financial results for the whole organization. Union membership and employee representation in works councils at the stores are actively discouraged; according to the union representative, "outlets where workers organize themselves are often closed to set an example" (Geppert et al. 2015; Oltermann 2014).

In terms of the Pragmatist Critical perspective developed in this paper, the situation at Lidl appears ethically highly problematic. A quite pervasive discrepancy between the espoused values and principles on the one hand, and the actual activities and work practices on the other is discernible. Clearly, what Lidl promises on its website is grossly contradicted by existing social, material and organizational conditions. Misrecognition and disrespect seem involved in all spheres, as the physical and psychological integrity of employees is invaded, their rights to participate and be respected are denied, and employees' habits, traits, convictions and ways of life are depreciated, even when they are displayed outside Lidl. No effort is being made to engage employees in organizational problem-solving through social cooperation and reflection. No use is being made of the mental, intellectual and physical capabilities of employees. All these factors greatly impair the possibilities of Lidl employees to attain meaningful self-realization in their jobs. The case generally confirms suspicions about the effects of the capitalist system on the possibilities for human self-realization, cooperative inquiry and intelligent problem-solving within and through organizations. While in many aspects a seemingly extreme case, it does not appear to be far removed from recent developments in industrial and retail organizations across the world (e.g., Moore and Robinson 2016; Peck 2013). 


\section{Discussion and Conclusions}

This paper addresses the question to what extent Pragmatist and Critical conceptions of business ethics are compatible in a philosophical and practical sense. It appears possible to arrive at a Pragmatist Critical perspective on business ethics, through a mutual emphasis on the socialized nature of recognition, the rational solution of societal and organizational problems through free and unrestrained social cooperation in inquiry, and the pivotal importance of the social division of labor for both human self-realization and democracy.

In spite of theoretical convergences, important points of difference remain regarding the relation between theory and practice. Dewey did not share Critical theory's inclination toward grand social meta-theorizing, against which he posited a more modest practice of "fresh and unbiased" inquiry into concrete social problems and their causes (Frega 2014; Bohman 2002; Strydom 2011). Further, Dewey did not share Critical theory's general distrust of the public capacity to identify and resolve "pathologies of society," but instead proposed a joint liaison between intellectuals and the public in detecting and correcting societal problems (Decker 2012; Frega 2014; Joas 1992; Peters 1994). While thus mindful of the dangers of capitalism and societal power inequalities, Dewey was more optimistic and practice-oriented than most Critical theorists about the possibilities of successful public inquiry into societal problems.

However, two recent developments have brought some convergence here as well. Recently scholars involved in Critical management studies have revised their stance toward practical societal problems and issues. Like the Critical theorists in general, for a long time these Critical management scholars tended to disengage from practice, fearing colonization and perverting of their ideas by practitioners (Visser 2010). However, their aloofness from the "problems of men" more and more came to be regarded as inconsistent with attempts to promote social change, as reinforcing an inside-looking attitude, as preventing the articulation of positive wants and desires (instead of only negatively deconstructing the existing situation), and as reinforcing a cynical consciousness, in which Critical management scholars depend on and profit from the same organizational world they critique (Butler and Spoelstra 2014; Parker 2014). These concerns were translated into a new view of Critical management studies as Critically or progressively performative, purporting to "actively and subversively intervene in managerial discourse and practices," guided by an affirmative stance, an ethic of care, a pragmatic orientation, attending to potentialities and a normative orientation (Spicer et al. 2009, p. 544, 2016; Hartmann 2014; Wickert and Schaefer 2015).
These movements of Critical management scholars toward practice have been accompanied by recent movements of neo-Pragmatist scholars toward incorporating Critical theory in practical social inquiry. Such inquiry should not only be both interpretive and explanatory,

but also descriptive and normative at the same time. Such inquiry assumes neither a pure "insider" and participant standpoint (in the manner of hermeneutics), nor a pure "outsider" or observer standpoint (in the manner of naturalistic social theories). This distinctively normative standpoint characteristic of critical social inquiry... has been called the "perspective of a critical-reflective participant" (Bohman 2002, p. 503; Decker 2012).

It would amount to a form of social inquiry that starts with concrete problem-solving, but in a "negatively dialectical" process progressively delves deeper into the structural causes of problems by continuously but cooperatively questioning taken-for-granted assumptions and hegemonial power positions, by giving voice to normally silent voices inside and outside the organization, and by maintaining reflective openness until a particular deep form of insight and learning has been attained (Parker 2003; Spoelstra and Svensson 2016; Zanetti and Carr 2000).

Further, regarding practice, the example of Dewey as a life-long social and political activist could be a source of inspiration for Critical scholars to "Pragmatically walk their Critical talk," thus avoiding pervasive discrepancies in their own daily working life (Butler and Spoelstra 2014; Parker 2014). This could entail that Pragmatist Critical scholars are directly and actively involved in their own university, for example in employee councils, work groups and departmental meetings; that they apply Critical pedagogy in their classes whenever possible or necessary, for example by discussing different paradigms and bringing in Critical perspectives in mainstream business, economics and accounting courses and by engaging students in thinking outside their "mental boxes" (Fleming and Banerjee 2016); that they are vigilant in safeguarding an open, experimental and productive learning atmosphere against closed and defensive ideological reasoning from both the right and the left (Magala 2006); that they do not tacitly accept existing management hierarchies as given (Cabantous et al. 2016; Klikauer 2015), but actively explore alternative forms of organization, for example in cooperatives (Leca et al. 2014; Paranque and Willmott 2014), communities (Adler 2001) or anarchical forms (Wigger 2016).

As outlined in this paper, a Pragmatist Critical perspective contributes to a broadly emancipatory conception of business ethics that goes beyond profit, efficiency and productivity ends to consider environmental concerns and the interests of employees, clients and the community-at- 
large. A prima facie, it appears to be in line with stakeholder theory (e.g., Parmar et al. 2010; Wicks and Freeman 1998). However, stakeholder theory still basically is stakeholder capitalism; in fact it is a particular libertarian form of capitalism, championing personal freedom, individual property rights and a minimal state. It considers companies as merely apolitical voluntary associations, the "hegemony of the current order is natural and is generally seen as non-problematic... the interaction between the company and society is seen as harmonious and well integrated" (Jensen and Sandström 2013, p. 233; Freeman and Philips 2002). It seems that the reason why stakeholder theory can be safely advanced over shareholder theory is that relations between firms and society are considered basically harmonious and unproblematic, in which business ethics is viewed as a neutral pragmatist search for whatever works within the larger framework of capitalist society, but without questioning that framework itself.

A Pragmatist Critical perspective as conceived here looks beyond the capitalist order for viable and liberating alternatives. In the end, only one question regarding business ethics is deemed all-important: to what extent are humans considered as "means" for the attainment of certain "ends" (profit, efficiency, productivity, etc.) within organizations or systems, and to what extent does that prevent them from receiving full recognition as "ends" in themselves, i.e., as human beings, full of potential toward growth, self-realization and social self-determination.

Acknowledgements I thank René Ten Bos, Mike Geppert, Ivo De Loo, Angela Wigger, the Nijmegen performativity study group (Jacqueline Drost, Reinald Minnaar and Ed Vosselman), the participants of subtheme 44 "When critical research goes to work: Bridging pragmatist problem-solving and continental critique" (32th EGOS Colloquium, Naples, 7-9 July, 2016), and the Editor and three reviewers of the Journal of Business Ethics for their inspiring and thoughtful comments on earlier drafts.

\section{Compliance with Ethical Standards}

Conflict of interest This study is not funded by a particular grant. This article does not contain any studies with human participants or animals performed by any of the authors.

Open Access This article is distributed under the terms of the Creative Commons Attribution 4.0 International License (http://creative commons.org/licenses/by/4.0/), which permits unrestricted use, distribution, and reproduction in any medium, provided you give appropriate credit to the original author(s) and the source, provide a link to the Creative Commons license, and indicate if changes were made.

\section{References}

Adler, P. S. (2001). Market, hierarchy, and trust: The knowledge economy and the future of capitalism. Organization Science, $12(2), 215-234$.
Adler, P. S., Forbes, L. C., \& Willmott, H. (2008). Critical management studies. Academy of Management Annals, 1(1), $119-179$.

Adorno, T. W. (1941). Veblen's attack on culture: Remarks occasioned by the theory of the leisure class. Studies in Philosophy and Social Science, 9(3), 389-413.

Adorno, T. W. (1966). Negative Dialektik. Frankfurt am Main: Suhrkamp.

Adorno, T. W., Frenkel-Brunswik, E., Levinson, D. J., \& Sanford, R. N. (1950). The authoritarian personality. New York: Harper.

Almeder, R. (1987). A definition of Pragmatism. In H. Stachowiak (Ed.), Pragmatik: Handbuch Pragmatischen Denkens (Vol. II, pp. 99-107). Meiner: Hamburg.

Alvesson, M., Bridgman, T., \& Willmott, H. (2009). Introduction. In M. Alvesson, T. Bridgman, \& H. Willmott (Eds.), Oxford handbook of critical management studies (pp. 1-26). Oxford: Oxford University Press.

Alvesson, M., \& Willmott, H. (2012). Making sense of management: A critical introduction (2nd ed.). London: Sage.

Anderson, J. (2011). Situating Axel Honneth in the Frankfurt School tradition. In D. Petherbridge (Ed.), Axel Honneth: Critical essays (pp. 31-57). Leiden/Boston: Brill.

Argyris, C., \& Schön, D. A. (1996). Organizational learning II: Theory, method and practice. Reading, MA: Addison-Wesley.

Bernstein, R. J. (2010). The pragmatic turn. Cambridge: Polity.

Bohman, J. (2002). How to make a social science practical: Pragmatism, critical social science and multiperspectival theory. Millennium: Journal of International Studies, 31(3), 499-524.

Brandi, U., \& Elkjaer, B. (2011). Organizational learning viewed from a social learning perspective. In M. Easterby-Smith \& M. A. Lyles (Eds.), Handbook of organizational learning and knowledge management (2nd ed., pp. 23-41). New York: Wiley.

Brownlee, T. L. (2015). Alienation and recognition in Hegel's Phenomenology of Spirit. Philosophical Forum, 46(4), 377-396.

Butler, N., \& Spoelstra, S. (2014). The regime of excellence and the erosion of ethos in Critical management studies. British Journal of Management, 25(3), 538-550.

Cabantous, L., Gond, J. P., Harding, N., \& Learmonth, M. (2016). Critical essay: Reconsidering critical performativity. Human Relations, 69(2), 197-213.

Carr, A. (2000). Critical theory and the management of change in organizations. Journal of Organizational Change Management, 13(3), 208-220.

Cohen, J. (1990). Dualistic Critical theory and contemporary social movements. In P. Van Engelsdorp Gastelaars, S. Magala, \& O. Preuss (Eds.), Critical theory and the science of management (pp. 135-150). Rotterdam: Rotterdam University Press.

Cohen, M. D. (2007). Reading Dewey: Reflections on the study of routine. Organization Studies, 28(5), 773-786.

Colville, I., Hennestad, B., \& Thoner, K. (2014). Organizing, changing and learning: A sensemaking perspective on an ongoing "soap story". Management Learning, 45(2), 216-234.

Commager, H. S. (1950). The American mind: An interpretation of American thought and character since the 1880's. New Haven, CT: Yale University Press.

Connolly, K. (2008). German supermarket chain Lidl accused of snooping on staff. The Guardian, 27 March (https://www. theguardian.com/world/2008/mar/27/germany.supermarkets, Accessed 7 January 2017).

David, E. M. (1937). Besprechungen. Hook, Sidney, from Hegel to Marx: Studies in the intellectual development of Karl Marx. Zeitschrift für Sozialforschung, 6(1), 186-187.

Decker, K. S. (2012). Perspectives and ideologies: A pragmatic use for recognition theory. Philosophy and Social Criticism, 38(2), 215-226. 
Deen, P. (2011). Dialectical versus experimental method: Marcuse's review of Dewey's Logic: The theory of inquiry. Transactions of the Charles S. Peirce Society, 46(2), 242-257.

Deen, P. (2013). John Atkinson Hobson and the roots of John Dewey's economic thought. European Journal of the History of Economic Thought, 20(4), 646-665.

Denzin, N. K. (1996). Post-pragmatism. Symbolic Interaction, 19(1), $61-75$.

Dewey, J. (1896). The reflex arc concept in psychology. Psychological Review, 3(4), 357-370.

Dewey, J. (1922). Human nature and conduct: An introduction to social psychology. New York: Holt.

Dewey, J. (1938). Logic: The theory of inquiry. New York: Holt.

Dewey, J., \& Tufts, J. H. (1908). Ethics. New York: Holt.

Elkjaer, B. (2004). Organizational learning: The "third way". Management Learning, 35(4), 419-434.

Elkjaer, B., \& Simpson, B. (2011). Pragmatism: A lived and living philosophy: What can it offer to contemporary organization theory? In H. Tsoukas \& R. Chia (Eds.), Philosophy and organization theory (Research in the Sociology of Organizations) (Vol. 32, pp. 55-84). Emerald: Bingley.

Evans, K. G. (2000). Reclaiming John Dewey: Democracy, inquiry, pragmatism and public management. Administration and Society, 32(3), 308-328.

Farjoun, M., Ansell, C., \& Boin, A. (2015). Pragmatism in organization studies: Meeting the challenges of a dynamic and complex world. Organization Science, 26(6), 1787-1804.

Fleming, P., \& Banerjee, S. B. (2016). When performativity fails: Implications for Critical management studies. Human Relations, 69(2), 257-276

Freeman, R. E., \& Philips, R. A. (2002). Stakeholder theory: A libertarian defense. Business Ethics Quarterly, 12(3), 331-349.

Frega, R. (2014). Between pragmatism and critical theory: Social philosophy today. Human Studies, 37(1), 57-82.

Frega, R. (2015). Beyond morality and ethical life: Pragmatism and critical theory cross paths. Journal of Philosophical Research, 40(1), 63-96.

Fromm, E. (1932). Über Methode und Aufgabe einer analytischen Sozialpsychologie: Bemerkungen über Psychoanalyse und historischen Materialismus. Zeitschrift für Sozialforschung, 1(1-2), $28-54$.

Fromm, E. (1936). Sozialpsychologischer Teil. In M. Horkheimer (Ed.), Studien über Autorität und Familie: Forschungsberichte aus dem Institut für Sozialforschung (pp. 77-135, 230-238). Paris: Alcan.

Fromm, E. (1941). Escape from freedom. New York: Holt, Rinehart and Winston.

Fromm, E. (1984). The working class in Weimar Germany: A psychological and sociological study. Warwickshire: Berg.

George, F. E. (1973). Dewey and dialectics. In R. C. Whittemore (Ed.), Dewey and his influence: Essays in honor of George Estes Barton (Tulane Studies in Philosophy) (Vol. 22, pp. 22-37). The Hague: Martinus Nijhoff.

Geppert, M. (2015). Reflections on the methods of how we present and compare the political contents of our research: A prerequisite for critical institutional research. Journal of Management Inquiry, 24(1), 100-104.

Geppert, M., Williams, K., \& Wortmann, M. (2015). Micro-political game playing in Lidl: A comparison of store-level employment relations. European Journal of Industrial Relations, 21(3), 241-257.

Habermas, J. (1998). Ganz allein: wie sich der amerikanische Philosoph John Dewey 1929 auf "Die Suche nach Gewißheit" machte. Die Zeit, 31 (http://www.zeit.de/1998/31/Ganz_allein, Accessed 7 Februari 2016).
Hartmann, M. (2009). Perception of the experience: John Dewey in the German language reception. Allgemeine Zeitschrift für Philosophie, 34(3), 415-440.

Hartmann, R. K. (2014). Subversive functionalism: For a less canonical critique in critical management studies. Human Relations, 67(5), 611-632.

Hartmann, M., \& Honneth, A. (2006). Paradoxes of capitalism. Constellations, 13(1), 41-58.

Hollinger, D. A. (1980). The problem of Pragmatism in American history. Journal of American History, 67(1), 88-107.

Honneth, A. (1992). Integrity and disrespect: Principles of a conception of morality based on the theory of recognition. Political Theory, 20(2), 187-201.

Honneth, A. (1995). The struggle for recognition: The moral grammar of social conflicts. Cambridge: Polity.

Honneth, A. (1998). Democracy as reflexive cooperation: John Dewey and the theory of democracy today. Political Theory, 26(6), 763-783.

Honneth, A. (2001). Recognition or redistribution? Changing perspectives on the moral order of society. Theory, Culture and Society, 18(2-3), 43-55.

Honneth, A. (2004a). A social pathology of reason: On the intellectual legacy of critical theory. In F. Rush (Ed.), Cambridge companion to Critical theory (pp. 336-360). Cambridge: Cambridge University Press.

Honneth, A. (2004b). Organized self-realization: Some paradoxes of individualization. European Journal of Social Theory, 7(4), 463-478.

Honneth, A. (2005). A physiognomy of the capitalist form of life: A sketch of Adorno's social theory. Constellations, 12(1), 50-64.

Honneth, A. (2007). Recognition as ideology. In B. Van den Brink \& D. Owen (Eds.), Recognition and power: Axel Honneth and the tradition of critical social theory (pp. 323-347). Cambridge: Cambridge University Press.

Honneth, A. (2008). Reification and recognition: A new look at an old idea. In M. Jay (Ed.), Reification: A new look at an old idea (pp. 17-94). Oxford: Oxford University Press.

Honneth, A. (2010a). The pathologies of individual freedom: Hegel's social theory. Princeton, NJ: Princeton University Press.

Honneth, A. (2010b). Work and recognition: A redefinition. In $\mathrm{H}$. C. Schmidt am Busch \& C. F. Zurn (Eds.), The philosophy of recognition: Historical and contemporary perspectives (pp. 223-240). Lanham: Lexington.

Honneth, A. (2014). Freedom's right: The social foundations of democratic life. New York: Columbia University Press.

Honneth, A., \& Sutterlüty, F. (2011). Normative Paradoxien der Gegenwart: Eine Forschungsperspektive. WestEnd: Neue Zeitschrift für Sozialforschung, 8(1), 67-85.

Horkheimer, M. (1935). Zum Problem der Wahrheit. Zeitschrift für Sozialforschung, 4(3), 321-365.

Horkheimer, M. (1937). Traditionelle und kritische Theorie. Zeitschrift für Sozialforschung, 6(2), 245-294.

Horkheimer, M. (1941). Notes on Institute activities. Studies in Philosophy and Social Science, 9(1), 121-123.

Horkheimer, M. (1947). Eclipse of reason. New York: Oxford University Press.

Islam, G. (2012). Recognition, reification, and practices of forgetting: Ethical implications of human resource management. Journal of Business Ethics, 111(1), 37-48.

Jacobs, D. C. (2004). A pragmatist approach to integrity in business ethics. Journal of Management Inquiry, 13(3), 215-233.

Jay, M. (1973). The dialectical imagination: A history of the Frankfurt School and the Institute of Social Research, 1923-1950. London: Heinemann.

Jensen, T., \& Sandström, J. (2013). In defense of stakeholder pragmatism. Journal of Business Ethics, 114(2), 224-237. 
Jermier, J. M. (1998). Introduction: Critical perspectives on organizational control. Administrative Science Quarterly, 43(2), $235-256$.

Joas, H. (1992). An underestimated alternative: America and the limits of "critical theory". Symbolic Interaction, 15(3), 261-275.

Joas, H. (1993). Pragmatism and social theory. Chicago: University of Chicago Press.

Johnson, P. (2014). Sociology and the critique of neoliberalism: Reflections on Peter Wagner and Axel Honneth. European Journal of Social Theory, 17(4), 516-533.

Jordan, S. (2010). Learning to be surprised: How to foster reflective practice in a high-reliability context. Management Learning, 41(4), 391-413.

Keleman, M., \& Rumens, N. (2008). An introduction to critical management research. Thousand Oaks, CA: Sage.

Keucheyan, R. (2013). The left hemisphere: Mapping critical theory today. London: Verso.

Klikauer, T. (2012). Hegel's philosophy: Ethics, recognition and oppression. Philosophy and Social Criticism, 38(6), 651658.

Klikauer, T. (2015). Critical management studies and Critical theory: A review. Capital and Class, 39(2), 197-220.

Langman, L. (2014). Bringing the Critical back in: Toward the resurrection of the Frankfurt School. In H. F. Dahms (Ed.), Mediations of social life in the 21st century (Current Perspectives in Social Theory) (Vol. 32, pp. 195-227). Emerald: Bingley.

Leca, B., Gond, J. P., \& Cruz, L. B. (2014). Building "critical performativity engines" for deprived communities: The construction of popular cooperative incubators in Brazil. Organization, 21(5), 683-712.

Lee, H. N. (1973). Dewey and the behavioral theory of meaning. In R. C. Whittemore (Ed.), Dewey and his influence: Essays in honor of George Estes Barton (Tulane Studies in Philosophy) (Vol. 22, pp. 51-62). The Hague: Martinus Nijhoff.

Lidl (2017). http://www.lidl.co.uk/en/1919.htm, Accessed 7 January 2017.

Magala, S. (2006). Critical theory: 15 years later. Critical Perspectives on International Business, 2(3), 183-194.

Marcuse, H. (1939). Besprechungen. Dewey, John, Logic: The Theory of Inquiry. Zeitschrift für Sozialforschung, 8(1-2), 221-228.

Marcuse, H. (1941). Reviews. Dewey, John, Theory of Valuation. Studies in Philosophy and Social Science, 9(1), 144-148.

Martela, F. (2015). Fallible inquiry with ethical ends-in-view: A Pragmatist philosophy of science for organizational research. Organization Studies, 36(4), 537-563.

Midtgarden, T. (2012). Critical Pragmatism: Dewey's social philosophy revisited. European Journal of Social Theory, 15(4), 505-521.

Moore, P., \& Robinson, A. (2016). The quantified self: What counts in the neo-liberal workplace. New Media and Society, 18(11), 2774-2792.

Oltermann, P. (2014). Germany's Lidl seen overtaking big rivals Tesco, Carrefour and Aldi. The Guardian, 23 June (https://www. theguardian.com/business/2014/jun/23/lidl-germany-overtaketesco-carrefour-aldi, Accessed 31 April 2017).

Ormerod, R. (2006). The history and ideas of Pragmatism. Journal of the Operational Research Society, 57(8), 892-909.

Outhwaite, W. (2009). Recognition, reification and (dis)respect. Economy and Society, 38(2), 360-367.

Painter-Morland, M., \& Ten Bos, R. (2011). Introduction: Critical crossings. In M. Painter-Morland \& R. Ten Bos (Eds.), Business ethics and continental philosophy (pp. 1-14). Cambridge: Cambridge University Press.
Painter-Morland, M., \& Ten Bos, R. (2016). Should environmental concern pay off? A Heideggerian perspective. Organization Studies, 37(4), 547-564.

Paranque, B., \& Willmott, H. (2014). Cooperatives - saviors or gravediggers of capitalism? Critical performativity and the John Lewis Partnership. Organization, 21(5), 604-625.

Parker, M. (2003). Business, ethics and business ethics: Critical theory and negative dialectics. In M. Alvesson \& H. Willmott (Eds.), Studying management Critically (pp. 197-219). Thousand Oaks, CA: Sage.

Parker, M. (2014). University Ltd: Changing a business school. Organization, 21(2), 281-292.

Parmar, B. L., Freeman, R. E., Harrison, J. S., Wicks, A. C., Purnell, L., \& De Colle, S. (2010). Stakeholder theory: The state of the art. Academy of Management Annals, 4(1), 403-445.

Peck, J. (2013). Explaining (with) neoliberalism. Territory, Politics, Governance, 1(2), 132-157.

Peters, J. D. (1994). The curious reception of Pragmatism examined and exemplified. Reviews in American History, 22(4), 679-684.

Petersen, A., \& Willig, R. (2004). Work and recognition: Reviewing new forms of pathological developments. Acta Sociologica, 47(4), 338-350.

Ratner, J. (Ed.). (1939). Intelligence in the modern world: John Dewey's philosophy. New York: Modern Library.

Ray, L. (2004). Pragmatism and Critical theory. European Journal of Social Theory, 7(3), 307-321.

Rorty, R. (2003). The invisible philosopher. New York Times, 9 March (http://www.nytimes.com/2003/03/09/books/the-invisi ble-philosopher.html, Accessed 7 February 2016).

Rose, G. (1978). The melancholy science: An introduction to the thought of Theodor W. Adorno. London: Macmillan.

Scherer, A. S. (2009). Critical theory and its contribution to Critical management studies. In M. Alvesson, T. Bridgman, \& $\mathrm{H}$. Willmott (Eds.), Oxford handbook of Critical management studies (pp. 29-51). Oxford: Oxford University Press.

Schön, D. A. (1992). The theory of inquiry: Dewey's legacy to education. Curriculum Inquiry, 22(2), 119-139.

Simpson, B. (2009). Pragmatism, Mead and the practice turn. Organization Studies, 30(12), 1329-1347.

Singer, A. E. (2010). Integrating ethics and strategy: A pragmatic approach. Journal of Business Ethics, 92(4), 479-491.

Smith, A. K. (1973). Dewey's transition piece: The "reflex arc" paper. In R. C. Whittemore (Ed.), Dewey and his influence: Essays in honor of George Estes Barton (Tulane Studies in Philosophy) (Vol. 22, pp. 122-141). The Hague: Martinus Nijhoff.

Spicer, A., Alvesson, M., \& Karreman, D. (2009). Critical performativity: The unfinished business of Critical management studies. Human Relations, 62(4), 537-560.

Spicer, A., Alvesson, M., \& Kärreman, D. (2016). Extending Critical performativity. Human Relations, 69(2), 225-249.

Spoelstra, S., \& Svensson, P. (2016). Critical performativity: The happy end of Critical management studies? In A. Prasad, P. Prasad, A. J. Mills, \& J. H. Mills (Eds.), Routledge companion to Critical management studies (pp. 69-79). New York: Routledge.

Steinberger, K. (2010). Der geheimnisvollste Unternehmer Deutschlands. Süddeutsche Zeitung, 19 May (http://www.sueddeutsche. de/wirtschaft/lidl-der-geheimnisvollste-unternehmer-deutsch lands-1.899752, Accessed 31 April 2017).

Stever, J. A. (1993). Technology, organization, freedom: The organizational theory of John Dewey. Administration and Society, 24(4), 419-433.

Stokes, P. (2011). Critical concepts in management and organization studies. New York: Palgrave Macmillan.

Strydom, P. (2011). Contemporary Critical theory and methodology. London: Routledge. 
Surie, G., \& Ashley, G. (2008). Integrating pragmatism and ethics in entrepreneurial leadership for sustainable value creation. Journal of Business Ethics, 81(1), 235-246.

Thayer, H. S. (1967). Pragmatism. In P. Edwards (Ed.), Encyclopedia of philosophy (Vol. 5, pp. 430-435). New York: MacMillan and Free Press.

Thompson, M. J. (2015). The neo-idealist paradigm shift in contemporary Critical theory. In H. F. Dahms (Ed.), Globalization, critique and social theory: Diagnoses and challenges (Current Perspectives in Social Theory) (Vol. 33, pp. 137-163). Bingley: Emerald.

Visser, M. (2010). Critical management studies and "mainstream" organization science: A proposal for a rapprochement. International Journal of Organizational Analysis, 18(4), 466-478.

Weick, K. E. (2004). Mundane poetics: Searching for wisdom in organization studies. Organization Studies, 25(4), 653-668.

Weick, K. E. (2006). Faith, evidence, and action: Better guesses in an unknowable world. Organization Studies, 27(11), 1723-1736.

Wickert, C., \& Schaefer, S. M. (2015). Towards a progressive understanding of performativity in Critical management studies. Human Relations, 68(1), 107-130.

Wicks, A. C., \& Freeman, R. E. (1998). Organization studies and the new pragmatism: Positivism, anti-positivism, and the search for ethics. Organization Science, 9(2), 123-140.
Wigger, A. (2016). Anarchism as emancipatory theory and praxis: Implications for Critical Marxist research. Capital and Class, 40(1), 129-145.

Williams, L. P. (1970). A liberal's perspective on the dismal science: John Dewey's view of economic theory and practice. Educational Theory, 20(2), 177-188.

Winter, S. G. (2013). Habit, deliberation, and action: Strengthening the micro-foundations of routines and capabilities. Academy of Management Perspectives, 27(2), 120-137.

Wray-Bliss, E. (2009). Ethics: Critique, ambivalence, and infinite responsibilities (unmet). In M. Alvesson, T. Bridgman, \& H. Willmott (Eds.), Oxford handbook of Critical management studies (pp. 268-283). Oxford: Oxford University Press.

Yanow, D., \& Tsoukas, H. (2009). What is reflection-in-action? A phenomenological account. Journal of Management Studies, 46(8), 1339-1364.

Zanetti, L. A., \& Carr, A. (2000). Contemporary Pragmatism in public administration: Exploring the limitations of the "third productive reply". Administration and Society, 32(4), 433-452.

Zurn, C. F. (2015). Axel Honneth: A Critical theory of the social. Cambridge: Polity. 